\title{
Gastrointestinal neuroendocrine neoplasms (GI-NENs): hot topics in morphological, functional, and prognostic imaging
}

\author{
Ginevra Danti ${ }^{1}$ [ $\cdot$ Federica Flammia ${ }^{1} \cdot$ Benedetta Matteuzzi $^{1} \cdot$ Diletta Cozzi $^{1} \cdot$ Valentina Berti $^{2} \cdot$ Giulia Grazzini $^{1}$. \\ Silvia Pradella ${ }^{1} \cdot$ Laura Recchia $^{3} \cdot$ Luca Brunese $^{3} \cdot$ Vittorio Miele $^{1}$
}

Received: 7 July 2021 / Accepted: 30 July 2021 / Published online: 24 August 2021

(c) The Author(s) 2021

\begin{abstract}
Neuroendocrine neoplasms (NENs) are heterogeneous tumours with a common phenotype descended from the diffuse endocrine system. NENs are found nearly anywhere in the body but the most frequent location is the gastrointestinal tract. Gastrointestinal neuroendocrine neoplasms (GI-NENs) are rather uncommon, representing around $2 \%$ of all gastrointestinal tumours and $20-30 \%$ of all primary neoplasms of the small bowel. GI-NENs have various clinical manifestations due to the different substances they can produce; some of these tumours appear to be associated with familial syndromes, such as multiple endocrine neoplasm and neurofibromatosis type 1. The current WHO classification (2019) divides NENs into three major categories: well-differentiated NENs, poorly differentiated NENs, and mixed neuroendocrine-non-neuroendocrine neoplasms. The diagnosis, localization, and staging of GI-NENs include morphology and functional imaging, above all contrast-enhanced computed tomography (CECT), and in the field of nuclear medicine imaging, a key role is played by ${ }^{68} \mathrm{Ga}$-labelled-somatostatin analogues $\left({ }^{68} \mathrm{Ga}\right.$-DOTA-peptides) positron emission tomography/computed tomography (PET/ $\mathrm{TC})$. In this review of recent literature, we described the objectives of morphological/functional imaging and potential future possibilities of prognostic imaging in the assessment of GI-NENs.
\end{abstract}

Keywords Neuroendocrine neoplasms · Gastrointestinal tract · Pathological correlation · Contrast-enhanced computed tomography $\cdot{ }^{68} \mathrm{Ga}$-DOTA-peptides PET $\cdot \mathrm{TC} \cdot$ Prognostic imaging

\section{Introduction}

Neuroendocrine neoplasms (NENs) are epithelial tumours that originate from the diffuse endocrine system cells. They share the expression of neuroendocrine markers (such as chromogranin A and synaptophysin) and can secrete multiple different aminoacids and polypeptides, which may result in several clinical syndromes [1]. The neuroendocrine system is distributed over several organs, so NENs have many different denominations [2]: medullary carcinoma in thyroid, 
carcinoid, large-cell neuroendocrine carcinoma and smallcell carcinoma in lung and thymus, paraganglioma in extrasurrenal paraganglia, pheochromocytoma in adrenals and Merkel cell carcinoma in the skin.

NENs are most frequent in gastrointestinal tract (about $70 \%$ of cases), followed by lung (around $25 \%$ of cases) and pancreas [3].

Gastrointestinal neuroendocrine neoplasms (GI-NENs) are rather uncommon, representing around $2 \%$ of all gastrointestinal tumours and $20-30 \%$ of all primary neoplasms of the small bowel $[4,5]$; they derive from enterocromaffin cells and are predominantly situated in the distal ileum [5, 6].

Clinically, we can classify NENs into non-functioning and functioning tumours. The functioning tumours secrete substances that cause appreciable clinical symptoms, whereas the non-functioning neoplasms do not secrete any substance or the substance produced is inactive. NENs can be sporadic, be the only manifestation of a disease, or be part of a multiple endocrine neoplasm (MEN), together with other endocrine tumours [2]. In addition to MEN, GI-NENs can associate with other genetic syndromes such as Von Hippel-Lindau and Neurofibromatosis type 1 [3]. At the time of diagnosis, only $15 \%$ of patients have the typical carcinoid syndrome, characterized by facial flushing, diarrhoea, or bronchospasm due to serotonin hypersecretion; otherwise, patients who present non-specific symptoms, such as weight loss, bleeding, and abdominal pain, are asymptomatic [7-9]. Carcinoid syndrome can facilitate NENs's detection, despite many patients have advanced disease at diagnosis with distant metastases, mainly to the regional lymph nodes, liver, and bone [10-12]. Just over half of GI-NENs are diagnosed in the emergency setting with symptoms of gastrointestinal obstruction or bleeding [4].

According to the current World Health Organization (WHO) 2019 classification, based on the histopathological findings (Ki-67 index and mitotic rate), GI-NENs can be divided into three categories: well-differentiated NENs, poorly differentiated NENs, and mixed neuroendocrine-nonneuroendocrine neoplasms (MiNEN). Well-differentiated NENs are divided into grade 1 (Ki-67 index $<3$, mitotic rate $<2$ ), grade 2 (Ki-67 index 3-20, mitotic rate 2-20), and grade 3 (Ki-67 index $>20$, mitotic rate $>20$ ). Poorly differentiated NENs (Ki-67 index $>20 \%$ and mitotic index $>20$ ) have a neuroendocrine component of more than $30 \%$ of the tumour. The last group consists of mixed neuroendocrinenon-neuroendocrine neoplasms (MiNEN) and has instead a non-neuroendocrine component of more than $30 \%$; these may also be well differentiated or poorly differentiated [13].

Diagnostic imaging plays an important role in diagnosis, staging, and follow-up of GI-NENs [4, 14]. Several imaging techniques are used for this objective, in particular in the field of morphology imaging, we have abdominal ultrasound
(US), contrast-enhanced computed tomography (CECT), and magnetic resonance imaging (MRI); for functional imaging, we rely on somatostatin receptor scintigraphy with

${ }^{111}$ Indium-pentetreotide $\left({ }^{111} \mathrm{In}\right.$-Octreoscan $),{ }^{68} \mathrm{Ga}$-labelledsomatostatin analogues $\left({ }^{68} \mathrm{Ga}\right.$-DOTA-peptides $)$ positron emission tomography/computed tomography (PET/TC), and ${ }^{18}$ FFluorodeoxyglucose-positron emission tomography $\left({ }^{18}\right.$ F-FDG-PET) $[11,14]$.

In this review of recent literature, we aimed to evaluate the principal imaging features of GI-NENs to stratify patients into more defined clinical categories and to provide insights for precision medicine and appropriate treatments.

\section{Morphological imaging}

Radiologic imaging plays a key role in the diagnosis, staging, and follow-up of GI-NENs [4, 14, 15].

The main techniques involved in abdominal radiology are ultrasound (US), contrast-enhanced computed tomography (CECT), and magnetic resonance imaging (MRI); this type of imaging is used to determine the size and location of primary tumour, as well as for staging and for evaluation of potential treatment choices.

Abdominal ultrasound is a radiation-free imaging examination [16, 17], but has a restricted role in the evaluation of gastrointestinal disease [18, 19]. Depending on location, sensitivity of abdominal US in revealing GI-NENs has variable percentage values (around 12-28\%) [20]. Walczyk et al. reported how GI-NEN appears as a mass arising from the walls of gastrointestinal tract, and it may occur as hypoechoic lesions with a hyperechoic rim or as hyperechoic lesions (Fig. 1) [20, 21]. However, US examination is limited by operator dependence, it is not a panoramic method and visualization is confined to the field of investigation [20].

To date, the most widely used imaging modality for the detection of GI-NENs is undoubtedly CECT [4, 22-26], which allows diagnosis, staging, pre- and post-treatment evaluation and follow-up of these neoplasms (Fig. 2). A standard CECT protocol can be employed for both diagnosis and follow-up; patients can be scanned in the supine position with craniocaudal apnoea scans and should undergo non-contrast and contrast-enhanced CT scanning. Iodinated contrast medium can be injected into the antecubital vein at a flow rate of 3-4 mL/s using an automatic injector, immediately followed by a saline flush $(40-50 \mathrm{~mL})$. Contrastenhanced biphasic images can be achieved during the arterial phase (30-35 s after injection onset) and the portal venous phase (70-75 s after injection onset) [27]. Enterographic computed tomography is a hybrid procedure that combines the techniques of intubation-infusion of small bowel imaging with those of conventional abdominal CT [28-30]. CT enterography has been shown to be useful in depicting 
Fig. 1 Gastrointestinal neuroendocrine neoplasms (G1). Transabdominal ultrasonography demonstrates a mass involving the appendix as a hypoechogenic lesion with a hyperechogenic border (white arrow)
Fig. 2 Gastric neuroendocrine neoplasm (G1). Axial and coronal contrast-enhanced CECT images in the arterial and portal venous phases $(\mathbf{a}, \mathbf{b}, \mathbf{c})$ demonstrate an hypervascular intraluminal nodular mass of the gastric antrum (white arrow). In the inferior abdomen $(\mathbf{d})$, ascites is appreciated (white star)
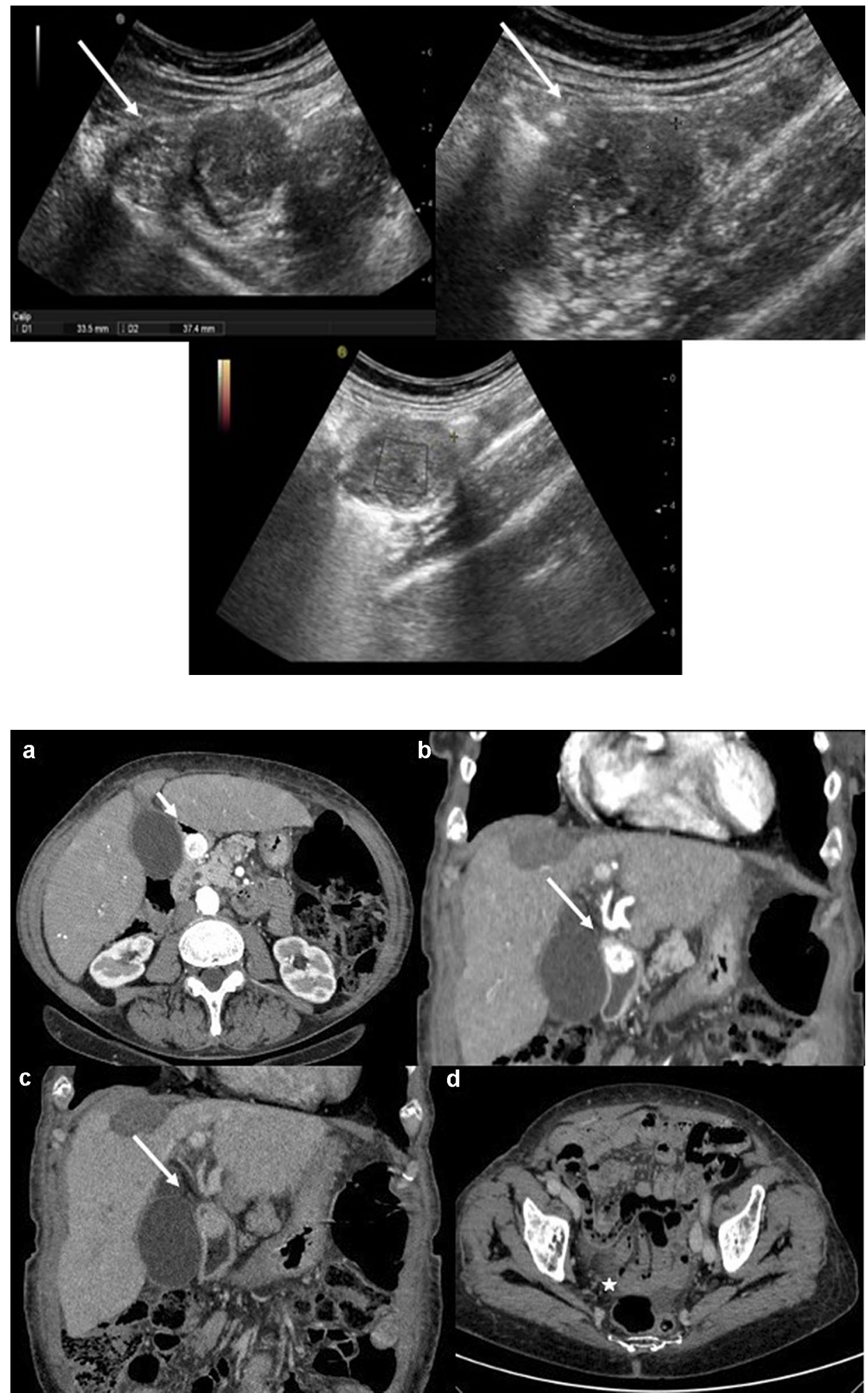

small bowel parietal abnormalities and to be superior to conventional CT in this field; it has already been described by Kamaoui et al. that the sensitivity of CT enteroclysis in identifying small bowel NENs is $100 \%$ with a specificity of $96 \%$ [31]. At the time of diagnosis, approximately, half of patients with GI-NENs manifest advanced disease with metastases, most frequently localized to loco-regional lymph node stations, liver parenchyma, or bone [12-15] (Figs. 3, 4). The imaging appearance of NENs is widely variable, and it depends on localization, size, and margins, relationship to 


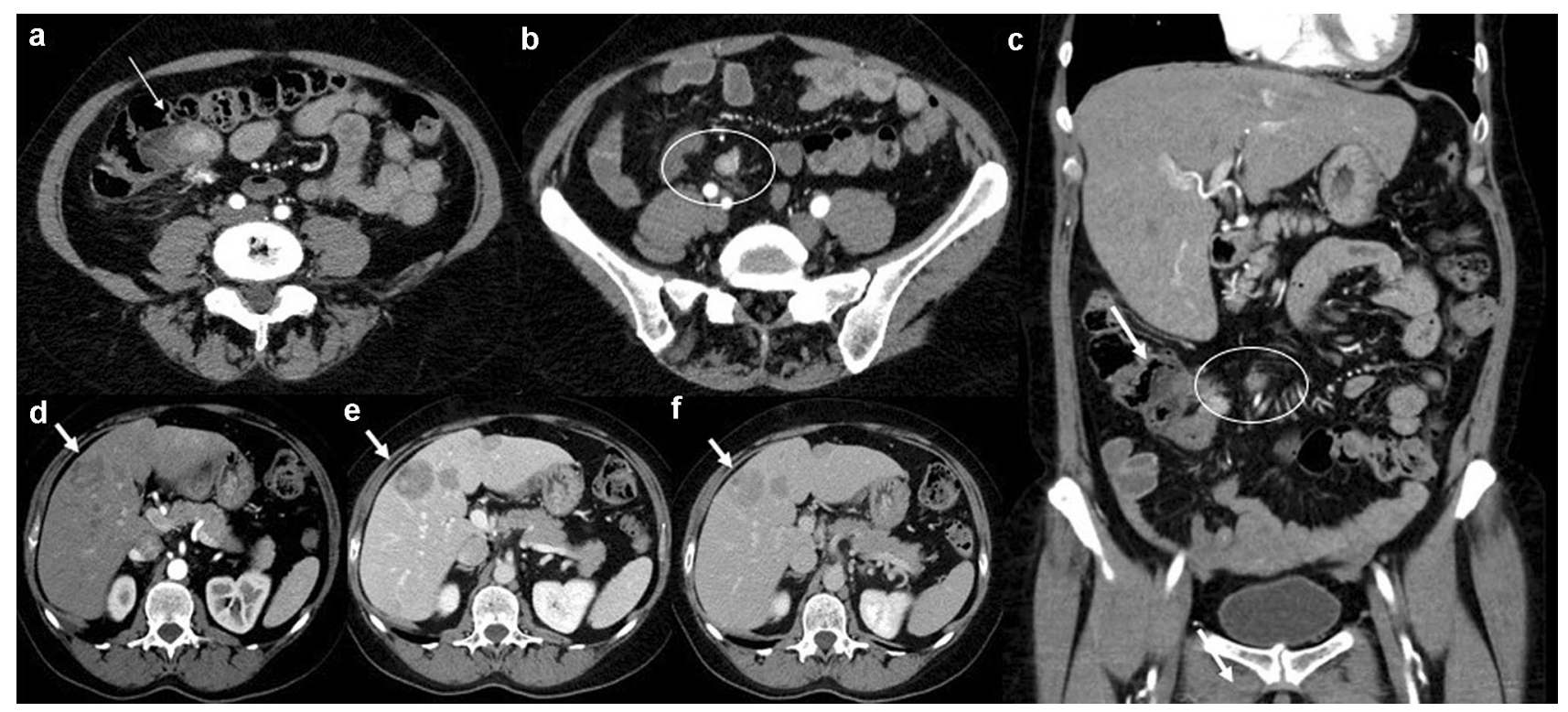

Fig. 3 Gastrointestinal neuroendocrine carcinoma (NEC) in the terminal ileum. Axial $(\mathbf{a}, \mathbf{b})$ and coronal $(\mathbf{c})$ contrast-enhanced CECT images in the arterial phase demonstrate a well-circumscribed enhancing mass (white arrows) of the terminal ileum involving ileocecal valve; in the mesenteric fat near the primary tumour, there is a mesenteric mass (b, c. white circle) with desmpplastic reaction. Arterial phase (d), portal venous phase (e) and equilibrium phase (f) contrast-enhanced MDCT show multiple hypervascular liver metastases (with arrows) with central necrosis

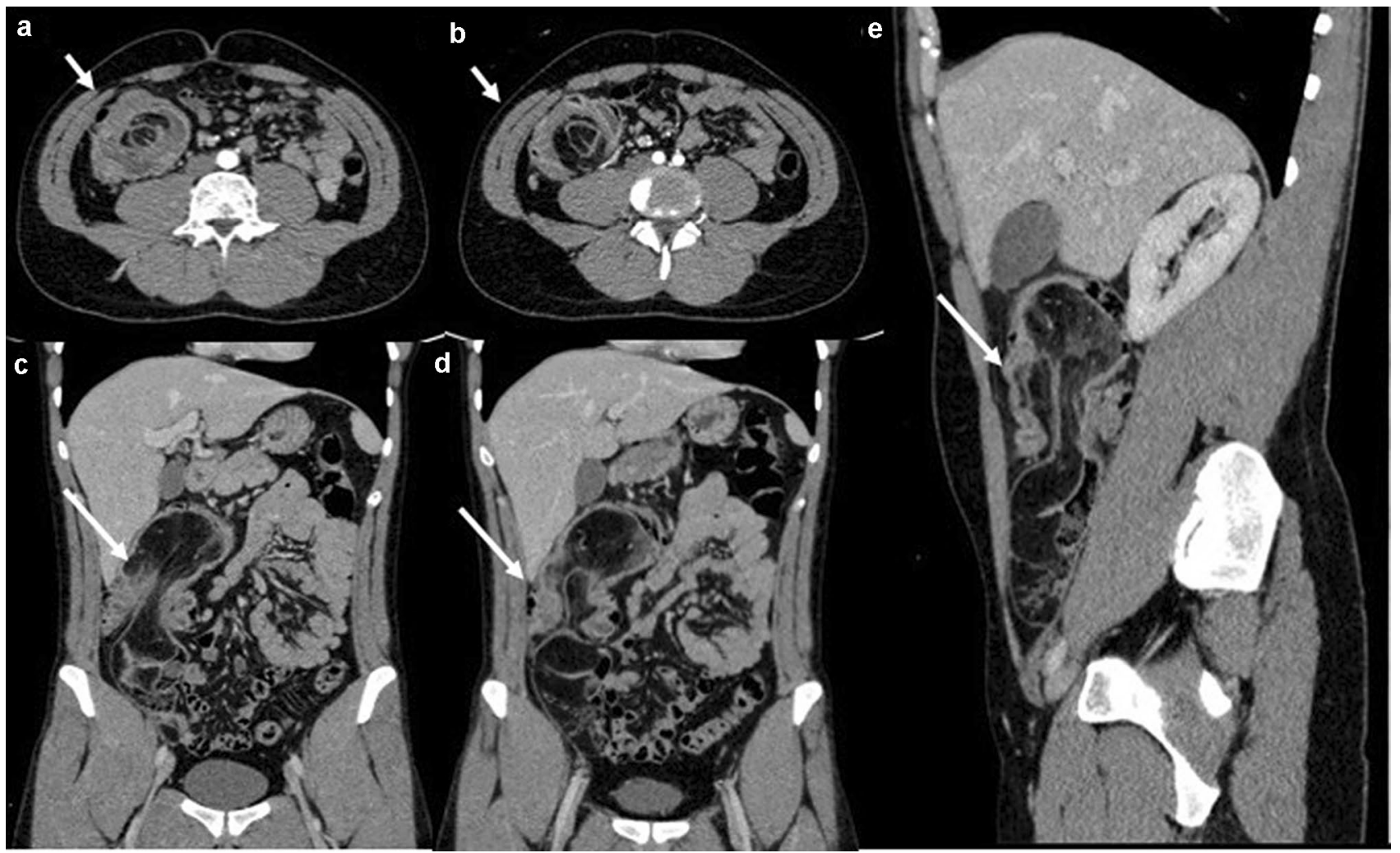

Fig. 4 Gastrointestinal neuroendocrine neoplasm (G3) in the cecum. Axial (a, b), coronal (c, d) and sagittal (e) CECT image in the arterial $(\mathbf{a}, \mathbf{b})$ and portal venous phase $(\mathbf{c}, \mathbf{d}, \mathbf{e})$ demonstrate an irregular bowel wall thickening of the cecum-ascendent colon, with intestinal intussusception (white arrows) 
the bowel wall and the presence of intralesional alterations (haemorrhage, calcifications, necrosis, cystic degeneration, and ulceration) that modify its densitometric homogeneity and contrastographic pattern $[4,11]$. After contrast medium injection, these gastrointestinal neoplasms may appear as a hypervascular nodular swelling originating from the intestinal wall or as a localized thickening of the wall [11] (Fig. 4). The boundary between the tumour and the adjacent tissue may be well or poorly defined; indeed, these lesions may have smooth, regular margins or jagged and irregular edges $[4,11]$.

They are typically solid, but may have intralesional necrosis or cystic degeneration and, frequently, coarse or thin calcifications. Among the extra-intestinal manifestations of GI-NENs, the most typical is mesenteric metastasis associated with a desmoplastic reaction; this metastasis presents as a solid mass in the mesenteric fat adjacent to the primary neoplasm, associated with soft tissue rays, that radiate from the central mass to the small bowel. These extra-intestinal signs can cause complications such as kinking or angulation of bowel [4]. Other manifestations detectable at CECT are invasion of adjacent organs, omental/peritoneal involvement, metastases (lymphnode and liver), and ascites [12,13] (Fig. 5). Many studies have demonstrated the correlation between CT features and pathological classification, revealing statistically significant differences between well-differentiated NENs and poorly differentiated NENs in terms of lesion size, growth, intra- or extra-intestinal involvement, zone of intralesional alterations, mesenteric fat infiltration and metastases; indeed, the finding on CT examination of lesions larger than $4 \mathrm{~cm}$ with necrotic or cystic areas in context, circumferential growth with transmural invasion, extra-intestinal involvement with mesenteric fat infiltration and lymphadenopathies, is more common in poorly differentiated NENs [4].

Magnetic resonance imaging has an excellent soft tissue contrast [32-34] and, as abdominal US, it is a radiation-free imaging examination. The standard protocol for the evaluation of GI-NENs provides T1 and T2-weighted sequences, diffusion-weighted imaging (DWI), and dynamic contrastenhanced imaging after administration of contrast medium [35-37]. Usually, GI-NENs appear hypointense on T1 and hyperintense on T2-weighted images, demonstrate a contrast enhancement pattern similar to that of CECT [8], and show diffusion restriction on DWI [38] (Fig. 6). Nevertheless, MRI is less used for the evaluation of patients with suspected GI-NENs because it is a time-consuming analysis and for its susceptibility to movement artefacts.

\section{Functional imaging of GI-NENs}

Nuclear medicine study aids morphological imaging in the assessment of GI-NENs and that is allowed since common feature of most GI-NENs is the expression of somatostatin receptors (SSTRs) [39, 40]. This characteristic is exploited by nuclear medicine imaging to detect sites of disease, using radio-labelled SST analogues (SSA). For functional imaging of GI-NENs, we use somatostatin receptor scintigraphy with ${ }^{111}$ Indium-pentetreotide ( ${ }^{111}$ In-Octreoscan),
Fig. 5 Gastrointestinal neuroendocrine neoplasm $(\mathrm{G} 3)$ in the terminal ileum. Axial contrastenhanced CT image in the arterial phase (a) demonstrates a bowel wall thickening (white line) of the terminal ileum and (b) a stellate soft tissue nodule (white star) in the mesentery. Under, there are many lymph nodes metastases (white circle) (c, d)

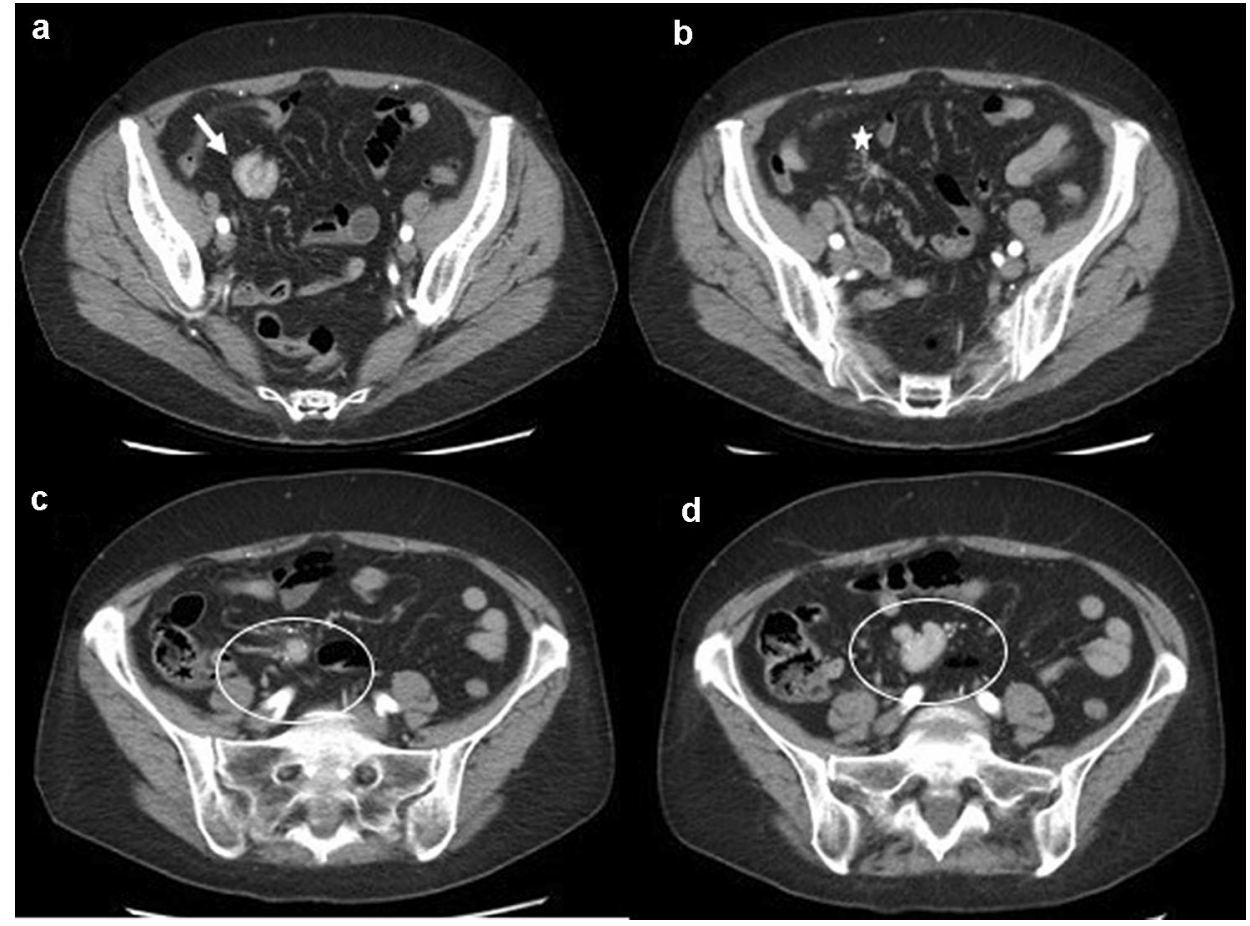




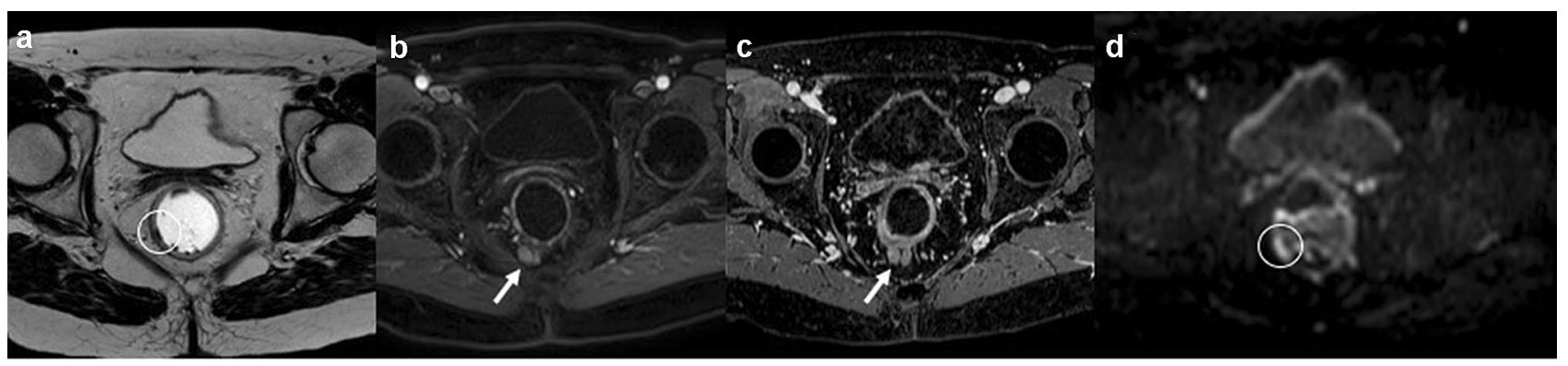

Fig. 6 Gastrointestinal neuroendocrine carcinoma of rectum (NEC); MRI axial and coronal T2w imaging (a, e), T2w FAT-SAT, dynamic contrast-enhanced imaging (c) and DwI (d) demonstrate a thickening of right wall of rectum (white arrow and white circle)

${ }^{68} \mathrm{Ga}$-labelled-somatostatin analogues $\left({ }^{68} \mathrm{Ga}\right.$-DOTA-peptides) positron emission tomography/computed tomography (PET/TC) and ${ }^{18}$ FFluorodeoxyglucose-positron emission tomography $\left({ }^{18} \mathrm{~F}-\mathrm{FDG}-\mathrm{PET}\right)$.

${ }^{111}$ Indium-pentetreotide (Octreoscan $\left.{ }^{\circledR}\right)$ uses a radiolabelled somatostatin analogues that detects neuroendocrine neoplasms by binding to characteristic somatostatin receptors displayed on the surface of GI-NEN cells [41-43]. Following administration of ${ }^{\mathbf{1 1 1}}$ Indium-pentetreotide, wholebody scintigraphy is performed to diagnose, localize, and stage GI-NENs, but at the same time, it is important to remember that a significant subgroup of NENs is somatostatin receptor-negative. For GI-NENs, these scans have associated positive predictive values of $84.6 \%$ and negative predictive values of $50 \%$ [44, 45].

Krausz et al. in their study reported how Octreoscan ${ }^{\circledR}$ accuracy in diagnosis of liver metastases was $82 \%$, this percentage is linked to several factors intrinsic to the method such as the low spatial resolution (usually around $1 \mathrm{~cm}$ ) and long acquisition timings; moreover, reduced Somatostatin receptor scintigraphy detection of known lesions may be associated with a lower density or absence of receptors [46].

A fundamental and innovative role in the identification of GI-NENs has been the use of 68Ga-labelled somatostatin analogues $\left({ }^{68} \mathrm{Ga}\right.$-DOTA-peptides) in positron emission tomography/computed tomography (PET/CT). Respect to Somatostatin receptor scintigraphy, ${ }^{68} \mathrm{Ga}$-DOTA-peptides have a higher sensitivity and spatial resolution and provide the possibility of image quantification [47-49].

Recently, a lot of study have reported the diagnostic superiority of ${ }^{68} \mathrm{Ga}$-DOTA-peptides over other diagnostic investigation in the detection of GI-NENs $[50,51]$. In particular, within of GI-NENs, ${ }^{68}$ Gallium-DOTA-peptides have been shown to have a better detection rate compared with CECT of primary tumour ( $89 \%$ vs $25 \%$ ) and carcinomatosis ( $88 \%$ vs $75 \%$ ), a higher detection rate than conventional Somatostatin receptor scintigraphy $(95.1 \%$ vs $45.3 \%$ ), and a lower radiation dose due to the shorter length of study ( $2 \mathrm{~h}$ ); this method has also high sensitivity $(93.5 \%)$ in the detection of liver metastasis from GI-NENs. $[52,53]$. With the increased use of multiple radionuclide ligands, it is hoped that ${ }^{68} \mathrm{Ga}$-DOTA-peptides will have a crucial role in the future in assigning class risk stratification and data for personalized treatment in patients with GI-NENs (Figs. 7, 8, 9).

A new hybrid chelator $\left({ }^{68} \mathrm{Ga}\right.$-DATA-peptides $)$ has recently been introduced. This one has the advantage of radio-labelling at room temperature in lesser time compared to ${ }^{68} \mathrm{Ga}$-DOTA-peptides, with high radiochemical yield in a istant kit-type fashion. In particular, although ${ }^{68} \mathrm{Ga}$-DOTA-peptides are nowadays the current standard for imaging of GI-NENs, recent studies have shown that ${ }^{68} \mathrm{Ga}$-DATA-peptides' elegant labelling profile is associated with diagnostic accuracy comparable to ${ }^{68} \mathrm{Gal}$ lium-DOTA-peptides [54, 55].

${ }^{18}$ FFluorodeoxyglucose-positron emission tomography allows to evaluate the metabolic activity of GI-NENs by studying the radio-labelled glucose metabolism. This method uses the increased glycolytic activity and increased expression of glucose transporters by tumour cells to identify these neoplasms compared to non-pathological tissue. [56]. A lot of study reported how ${ }^{18}$ F-FDG-PET has a limited role in the assessment of well-differentiated GI-NENs, but can be valuable for poorly differentiated GI-NENs [57, 58]. This is due to the fact that well-differentiated GINENs are more likely to express somatostatin receptors with high density, while poorly differentiated GI-NENs may display a lower density of somatostatin receptors but are more metabolically active, thus making them better visualized by ${ }^{18}$ F-FDG-PET. Additionally, Panagiotidis et al. in their study reported how the presence of increased glucose in GI-NENs highlights an increased propensity for invasion and metastasis, and how ${ }^{18} \mathrm{~F}$-FDG-PET accordingly has higher sensitivity in delineating disease extend, mainly in aggressive and high-grade tumours [58]. 

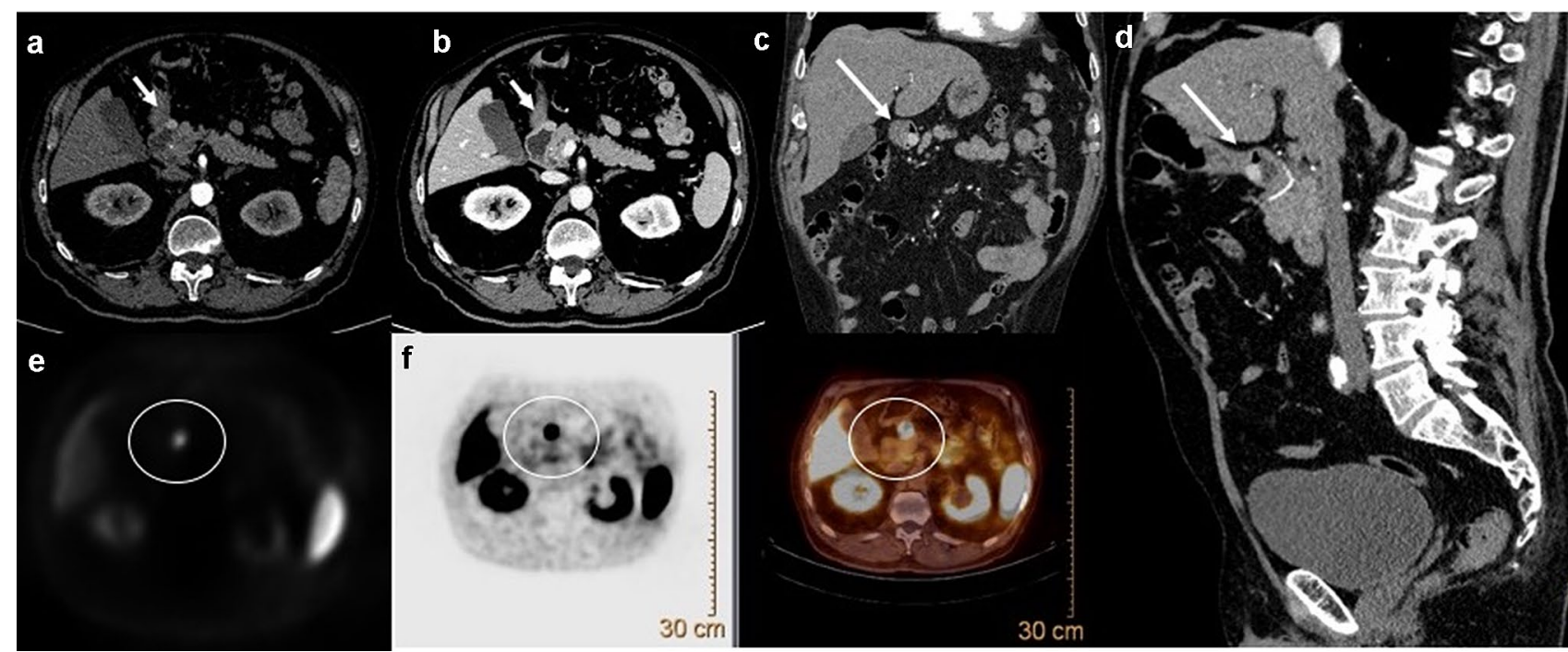

Fig. 7 Gastrointestinal neuroendocrine neoplasms in the gastric antrum (G1). Axial (a, b) coronal (c) and sagittal (d) contrastenhanced CECT images in the arterial $(\mathbf{a}, \mathbf{c}, \mathbf{d})$ and venous portal

phase (b) demonstrate a well-circumscribed ipervascular mass (white arrows) of the gastric antrum. At ${ }^{68} \mathrm{Ga}$-PET TC imaging $(\mathbf{e}, \mathbf{f})$ the lesion shows Ga uptake

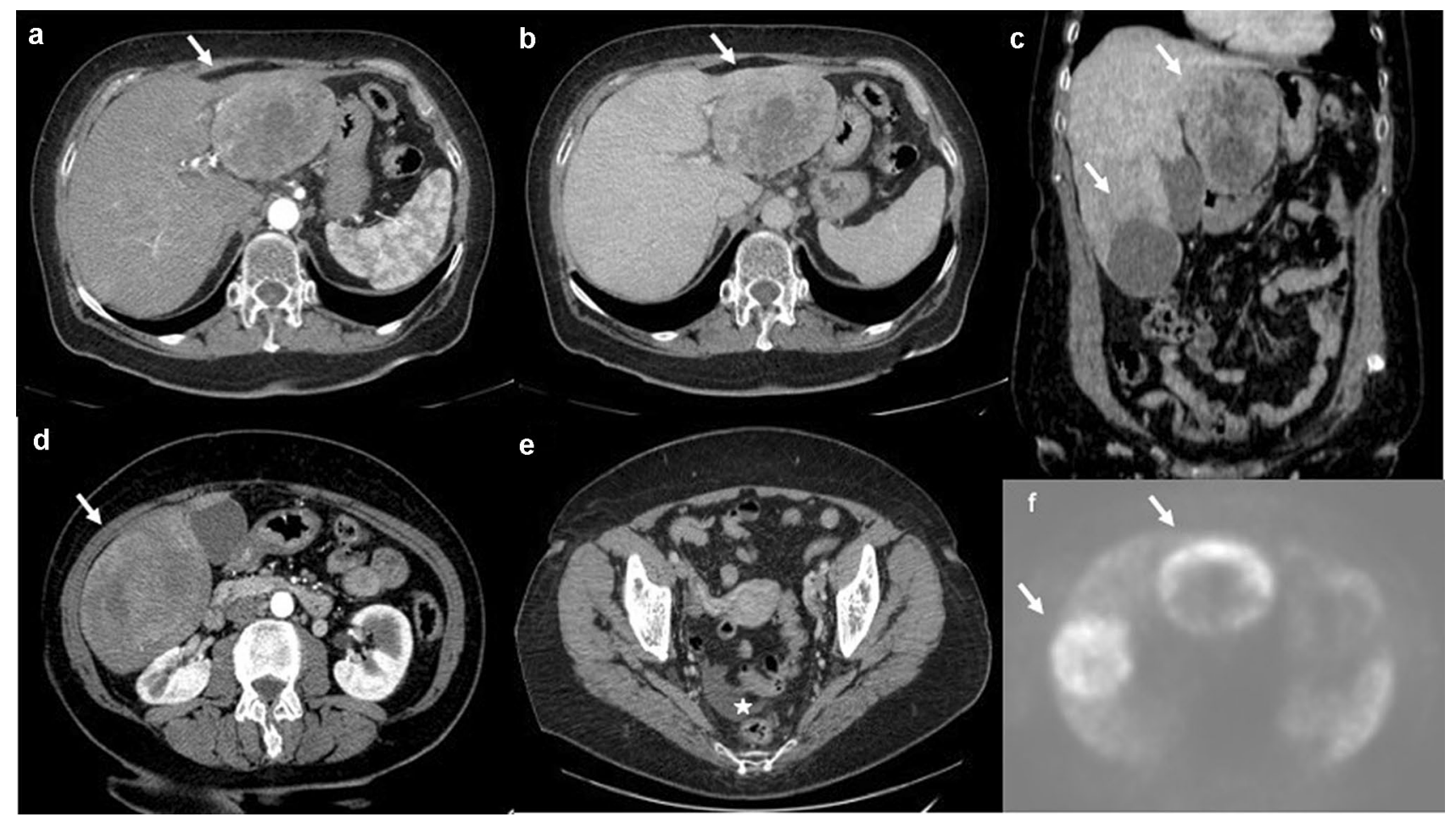

Fig. 8 Arterial phase $(\mathbf{a}, \mathbf{d})$ and portal venous phase $(\mathbf{b}, \mathbf{c})$ contrastenhanced CECT show multiple hypervascular liver metastases (withe arrows) of NEC, that become almost isodense on the portal venous phase except for central areas of necrosis. Ascites (e) is associated (withe star). At ${ }^{68} \mathrm{Ga}$-PET TC imaging (f) the liver lesions show $\mathrm{Ga}$ uptake 
Fig. 9 Axial pre-contrast image (a), arterial phase (b) and portal venous phase (c) contrastenhanced CECT show hypervascular liver metastasis (white arrows) of NEC that becomes almost isodense on the portal venous phase except for central areas of necrosis. At ${ }^{68} \mathrm{Ga}-\mathrm{PET}$ TC imaging (d) the liver lesion shows Ga uptake

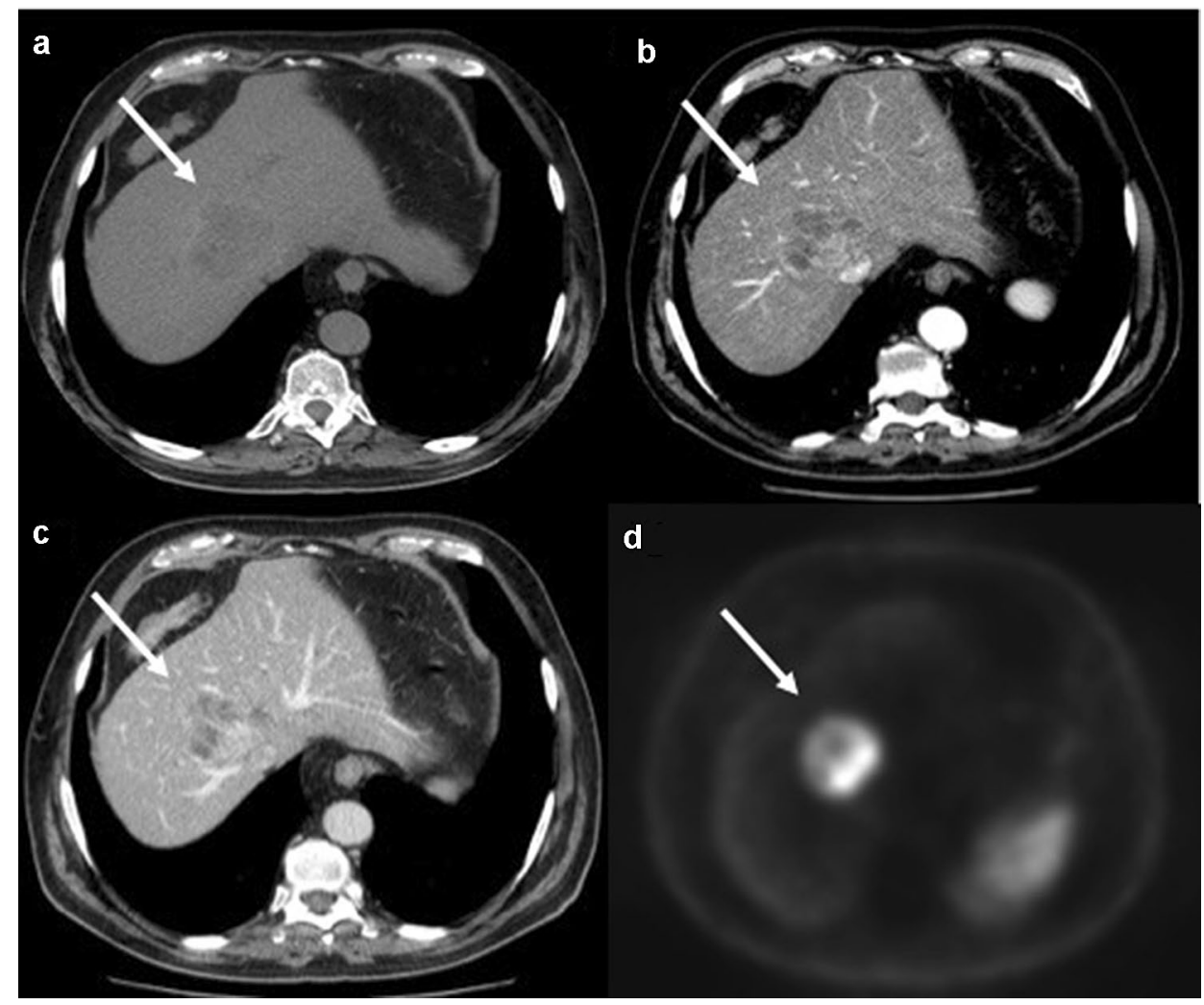

\section{Prognostic imaging of GI-NENs}

In the new era of precision medicine, radiomics is an emerging domain of research aiming to extract mineable highdimensional data from diagnostic images (mainly from CECT, PET or MRI) [59]. The notion underlying the process is that both morphological and functional images contain qualitative and quantitative information, which may reflect the underlying pathophysiology of a tissue. Radiomics' analyses can be performed in tumour regions, metastatic lesions, as well as in normal tissues [60]. The search method uses the following steps: acquisition of CT/RM/PET images of diagnostic quality, segmentation of neoplasm with definition of ROI of interest, extraction of radiomics features from the whole segmented volume or alternatively of some ROIs by appropriate software. The extracted features are generally divided into four categories: descriptive like shape, size, location; first-order statistics such as intensity histograms that relate pixel intensity ( $\mathrm{x}$-axis) to the number of pixels (y-axis) with analysis of mean, median, standard deviation, quartiles, kurtosis, skewness; second-order statistics concerns the analysis of the textures obtained, also known as "Haralick descriptors"; higher-order statistics represent repetitive and non-repetitive patterns extracted by Kernel transforms. Finally, statistical analysis and "data mining" are carried out to obtain diagnostic, predictive, and prognostic models by machine learning [61]. Several recent studies have begun to test the additional possibilities of quantitative imaging in many areas of abdominal oncology [62-69], but to the best of our knowledge, there are no known articles on this subject for GI-NENs. It would be interesting in the near future to extend quantitative imaging studies to this type of neoplasms, since the use of radiomics and texture analysis could be promising also in GI-NENs for more accurate diagnosis and differentiation, tumour risk stratification, management and assessment of treatment response.

\section{Conclusions}

In conclusion, morphological imaging plays a fundamental role in diagnosis, staging, and post-treatment follow-up of GI-NENs; functional imaging allows not only to detect the neoplasm but also may be useful in predicting differentiation grade of GI-NENs. One of the possible further developments for GI-NENs could be the evaluation of quantitative imaging with texture analysis, radiomic and radiogenomic features that may be useful in the prognostic assessment of these tumours. In fact, in GI-NENs, the main clinical question concerns the need of the patient risk stratification. Therefore, together with the overall clinical profiles (morphological and functional imaging, symptoms and individual risk for evolving disease), prognostic imaging could potentially 
be a decisional factor to stratify patients into more defined clinical categories for precision medicine and appropriate treatment.

Funding Open access funding provided by Università degli Studi di Firenze within the CRUI-CARE Agreement.

\section{Declarations}

Conflict of interest The authors declare that they have no conflict of interest related to the publication of this article.

Ethical standards The manuscript does not contain clinical studies or patient data.

Open Access This article is licensed under a Creative Commons Attribution 4.0 International License, which permits use, sharing, adaptation, distribution and reproduction in any medium or format, as long as you give appropriate credit to the original author(s) and the source, provide a link to the Creative Commons licence, and indicate if changes were made. The images or other third party material in this article are included in the article's Creative Commons licence, unless indicated otherwise in a credit line to the material. If material is not included in the article's Creative Commons licence and your intended use is not permitted by statutory regulation or exceeds the permitted use, you will need to obtain permission directly from the copyright holder. To view a copy of this licence, visit http://creativecommons.org/licenses/by/4.0/.

\section{References}

1. Danti G, Berti V, Abenavoli E, Briganti V, Linguanti F, Mungai F, Pradella S, Miele V (2020) Diagnostic imaging of typical lung carcinoids: relationship between MDCT, ${ }^{111} \mathrm{In}$-Octreoscan and ${ }^{18}$ F-FDG-PET imaging features with Ki-67 index. Radiol Med 125(8):715-729. https://doi.org/10.1007/s11547-020-01172-4

2. Rindi G, Wiedenmann B (2020) Neuroendocrine neoplasia of the gastrointestinal tract revisited: towards precision medicine. Nat Rev Endocrinol 16(10):590-607. https://doi.org/10.1038/ s41574-020-0391-3

3. Sahani DV, Bonaffini PA, Fernández-Del Castillo C, Blake MA (2013) Gastroenteropancreatic neuroendocrine tumors: role of imaging in diagnosis and management. Radiology 266(1):38-61. https://doi.org/10.1148/radiol.12112512

4. Grazzini G, Danti G, Cozzi D, Lanzetta MM, Addeo G, Falchini M, Masserelli A, Pradella S, Miele V (2019) Diagnostic imaging of gastrointestinal neuroendocrine tumours (GI-NETs): relationship between MDCT features and 2010 WHO classification. Radiol Med 124(2):94-102. https://doi.org/10.1007/ s11547-018-0946-8

5. Soyer P, Dohan A, Eveno C, Dray X, Hamzi L, Hoeffel C, Kaci R, Boudiaf M (2013) Carcinoid tumors of the small-bowel: evaluation with 64-section CT-enteroclysis. Eur J Radiol 82(6):943-950. https://doi.org/10.1016/j.ejrad.2013.02.013

6. Shinya T, Inai R, Tanaka T, Akagi N, Sato S, Yoshino T, Kanazawa S (2017) Small bowel neoplasms: enhancement patterns and differentiation using post-contrast multiphasic multidetector CT. Abdom Radiol (NY) 42(3):794-801. https://doi.org/10.1007/ s00261-016-0945-y

7. Modlin IM, Kidd M, Latich I, Zikusoka MN, Shapiro MD (2005) Current status of gastrointestinal carcinoids. Gastroenterology 128(6):1717-1751. https://doi.org/10.1053/j.gastro.2005.03.038
8. Oberg KE (2012) The management of neuroendocrine tumours: current and future medical therapy options. Clin Oncol (R Coll Radiol) 24(4):282-293. https://doi.org/10.1016/j.clon.2011.08. 006

9. Rockall AG, Reznek RH (2007) Imaging of neuroendocrine tumours (CT/MR/US). Best Pract Res Clin Endocrinol Metab 21(1):43-68. https://doi.org/10.1016/j.beem.2007.01.003

10. Yao JC, Hassan M, Phan A, Dagohoy C, Leary C, Mares JE, Abdalla EK, Fleming JB, Vauthey JN, Rashid A, Evans DB (2008) One hundred years after "carcinoid": epidemiology of and prognostic factors for neuroendocrine tumors in 35,825 cases in the United States. J Clin Oncol 26(18):3063-3072. https://doi.org/10. 1200/JCO.2007.15.4377

11. Kaltsas GA, Besser GM, Grossman AB (2004) The diagnosis and medical management of advanced neuroendocrine tumors. Endocr Rev 25(3):458-511. https://doi.org/10.1210/er.2003-0014

12. Metz DC, Jensen RT (2008) Gastrointestinal neuroendocrine tumors: pancreatic endocrine tumors. Gastroenterology 135(5):1469-1492. https://doi.org/10.1053/j.gastro.2008.05.047

13. Coriat R, Walter T, Terris B, Couvelard A, Ruszniewski P (2016) Gastroenteropancreatic Well-differentiated grade 3 neuroendocrine tumors: review and position statement. Oncologist 21(10):1191-1199. https://doi.org/10.1634/theoncologist. 2015-0476

14. Tsai SD, Kawamoto S, Wolfgang CL, Hruban RH, Fishman EK (2015) Duodenal neuroendocrine tumors: retrospective evaluation of CT imaging features and pattern of metastatic disease on dual-phase MDCT with pathologic correlation. Abdom Imaging 40(5):1121-1130. https://doi.org/10.1007/s00261-014-0322-7

15. Bicci E, Cozzi D, Ferrari R, Grazzini G, Pradella S, Miele V (2020) Pancreatic neuroendocrine tumours: spectrum of imaging findings. Gland Surg 9(6):2215-2224. https://doi.org/10.21037/ gs-20-537

16. Mocchegiani F, Vincenzi P, Coletta M, Agostini A, Marzioni M, Baroni GS, Giovagnoni A, Guerrieri M, Marmorale C, Risaliti A, Vivarelli M (2016) Prevalence and clinical outcome of hepatic haemangioma with specific reference to the risk of rupture: a large retrospective cross-sectional study. Dig Liver Dis 48(3):309-314. https://doi.org/10.1016/j.dld.2015.09.016

17. Iacobellis F, Segreto T, Berritto D, Nettuno F, Cozzolino S, Di Napoli D, Montella M, Natella R, Cappabianca S, Brunese L, Grassi R (2019) A rat model of acute kidney injury through systemic hypoperfusion evaluated by micro-US, color and PWDoppler. Radiol Med 124(5):323-330. https://doi.org/10.1007/ s11547-018-0962-8

18. Ierardi AM, Lucchina N, Petrillo M, Floridi C, Piacentino F, Bacuzzi A, Fonio P, Fontana F, Fugazzola C, Brunese L, Carrafiello G (2014) Systematic review of minimally invasive ablation treatment for locally advanced pancreatic cancer. Radiol Med 119(7):483-498. https://doi.org/10.1007/s11547-014-0417-9

19. Reginelli A, Mandato Y, Solazzo A, Berritto D, Iacobellis F, Grassi R (2012) Errors in the radiological evaluation of the alimentary tract: part II. Semin Ultrasound CT MR 33(4):308-317. https://doi.org/10.1053/j.sult.2012.01.016

20. Walczyk J, Sowa-Staszczak A (2019) Diagnostic imaging of gastrointestinal neuroendocrine neoplasms with a focus on ultrasound. J Ultrason 19(78):228-235. https://doi.org/10.15557/JoU. 2019.0034

21. Hyrdel R, Reznák I, Hyrdel P, Polácek H Jr, Polácek H, Hladká M, Agouba SM, Janík J, Laca L (2011) Neuroendokrinné nádory horného tráviaceho traktu, charakteristika a porovnanie efektivity lokalizacnej diagnostiky [Neuroendocrine tumours of the upper gastrointestinal tract, characteristics and comparison of localization diagnostics]. Vnitr Lek 57(12):1017-1024 
22. Bosman FT, Carneiro F, Hruban RH, Theise ND (eds) (2010) WHO classification of tumours of the digestive system, vol 3, 4th edn. IARC Press, Lyon

23. Danti G, Addeo G, Cozzi D, Maggialetti N, Lanzetta MM, Frezzetti G, Masserelli A, Pradella S, Giovagnoni A, Miele V (2019) Relationship between diagnostic imaging features and prognostic outcomes in gastrointestinal stromal tumors (GIST). Acta Biomed 90(5-S):9-19. https://doi.org/10.23750/abm.v90i5-S.8343

24. De Cecco CN, Buffa V, Fedeli S, Vallone A, Ruopoli R, Luzietti M, Miele V, Rengo M, Maurizi Enrici M, Fina P, Laghi A, David V (2010) Preliminary experience with abdominal dual-energy CT (DECT): true versus virtual nonenhanced images of the liver. Radiol Med 115(8):1258-1266. https://doi.org/10.1007/s11547010-0583-3 (English, Italian)

25. Addeo G, Beccani D, Cozzi D, Ferrari R, Lanzetta MM, Paolantonio P, Pradella S, Miele V (2019) Groove pancreatitis: a challenging imaging diagnosis. Gland Surg 8(Suppl 3):S178-S187. https://doi.org/10.21037/gs.2019.04.06

26. Grazzini G, Guerri S, Cozzi D, Danti G, Gasperoni S, Pradella S, Miele V (2021) Gastrointestinal stromal tumors: relationship between preoperative CT features and pathologic risk stratification. Tumori 23:300891621996447. https://doi.org/10.1177/03008 91621996447

27. Ippolito D, Maino C, Riva L, Pecorelli A, De Vito A, Lombardi S et al (2020) Iterative model-based CT reconstruction algorithm: the background and added clinical value. J Radiol Rev 7:185-195. https://doi.org/10.23736/S2723-9284.20.00029-4

28. Maglinte DD, Sandrasegaran K, Lappas JC, Chiorean M (2007) CT enteroclysis. Radiology 245(3):661-671. https://doi.org/10. 1148/radiol.2453060798

29. Hristova L, Placé V, Nemeth J, Boudiaf M, Laurent V, Soyer $P$ (2012) Small bowel tumors: spectrum of findings on 64-section CT enteroclysis with pathologic correlation. Clin Imaging 36(2):104-112. https://doi.org/10.1016/j.clinimag.2011.08.011

30. Soyer P, Aout M, Hoeffel C, Vicaut E, Placé V, Boudiaf M (2013) Helical CT-enteroclysis in the detection of small-bowel tumours: a meta-analysis. Eur Radiol 23(2):388-399. https://doi.org/10.1007/ s00330-012-2595-y

31. Kamaoui I, De-Luca V, Ficarelli S, Mennesson N, Lombard-Bohas C, Pilleul F (2010) Value of CT enteroclysis in suspected smallbowel carcinoid tumors. AJR Am J Roentgenol 194(3):629-633. https://doi.org/10.2214/AJR.09.2760

32. Taniyama Y, Suzuki T, Mikami Y, Moriya T, Satomi S, Sasano H (2005) Systemic distribution of somatostatin receptor subtypes in human: an immunohistochemical study. Endocr J 52(5):605-611. https://doi.org/10.1507/endocrj.52.605

33. Virgolini I, Ambrosini V, Bomanji JB, Baum RP, Fanti S, Gabriel M, Papathanasiou ND, Pepe G, Oyen W, De Cristoforo C, Chiti A (2010) Procedure guidelines for PET/CT tumour imaging with 68Ga-DOTA-conjugated peptides: 68Ga-DOTATOC, 68Ga-DOTA-NOC, 68Ga-DOTA-TATE. Eur J Nucl Med Mol Imaging 37(10):2004-2010. https://doi.org/10.1007/ s00259-010-1512-1513

34. De Herder WW (2014) GEP-NETS update: functional localisation and scintigraphy in neuroendocrine tumours of the gastrointestinal tract and pancreas (GEP-NETs). Eur J Endocrinol 170(5):R173R183. https://doi.org/10.1530/EJE-14-0077

35. Bader TR, Semelka RC, Chiu VC, Armao DM, Woosley JT (2001) MRI of carcinoid tumors: spectrum of appearances in the gastrointestinal tract and liver. J Magn Reson Imaging 14(3):261-269. https://doi.org/10.1002/jmri.1182

36. Dohan A, El Fattach H, Barat M, Guerrache Y, Eveno C, Dautry R, Mulé S, Boudiaf M, Hoeffel C, Soyer P (2016) Neuroendocrine tumors of the small bowel: evaluation with MR-enterography. Clin
Imaging 40(3):541-547. https://doi.org/10.1016/j.clinimag.2015. 12.016

37. Mennella M, Belfiore MP, Grassi R, Rella R, Vacca G, Rocco MP et al (2020) Role of multiparametric magnetic resonance imaging in the management of patients with Crohn's disease. J Radiol Rev 7:346-356. https://doi.org/10.23736/S2723-9284.20.00017-2

38. Kim KW, Krajewski KM, Nishino M, Jagannathan JP, Shinagare AB, Tirumani SH, Ramaiya NH (2013) Update on the management of gastroenteropancreatic neuroendocrine tumors with emphasis on the role of imaging. AJR Am J Roentgenol 201(4):811-824. https://doi.org/10.2214/AJR.12.10240

39. Lococo F, Treglia G, Cesario A, Paci M, Filice A, Versari A, Filosso PL (2014) Functional imaging evaluation in the detection, diagnosis, and histologic differentiation of pulmonary neuroendocrine tumors. Thorac Surg Clin 24(3):285-292. https://doi.org/10. 1016/j.thorsurg.2014.04.004

40. Arab WA, Collin Y, Sirois M, Levasseur MA, Paquet N (2018) The role of somatostatin-receptor scintigraphy in the diagnosis and staging of pulmonary carcinoid tumors. Clin Oncol 3:1391

41. Volante M, Bozzalla-Cassione F, Papotti M (2004) Somatostatin receptors and their interest in diagnostic pathology. Endocr Pathol Winter 15(4):275-291. https://doi.org/10.1385/ep:15:4:275

42. Reubi JC, Schaer JC, Waser B, Mengod G (1994) Expression and localization of somatostatin receptor SSTR1, SSTR2, and SSTR3 messenger RNAs in primary human tumors using in situ hybridization. Cancer Res 54(13):3455-3459

43. Squires MH 3rd, Volkan Adsay N, Schuster DM, Russell MC, Cardona K, Delman KA, Winer JH, Altinel D, Sarmiento JM, ElRayes B, Hawk N, Staley CA 3rd, Maithel SK, Kooby DA (2015) Octreoscan versus FDG-PET for neuroendocrine tumor staging: a biological approach. Ann Surg Oncol 22(7):2295-2301. https:// doi.org/10.1245/s10434-015-4471-x

44. Wang R, Zheng-Pywell R, Chen HA, Bibb JA, Chen H, Rose JB (2019) Management of gastrointestinal neuroendocrine tumors. Clin Med Insights Endocrinol Diabetes 12:1179551419884058. https://doi.org/10.1177/1179551419884058

45. Shi W, Johnston CF, Buchanan KD, Ferguson WR, Laird JD, Crothers JG, McIlrath EM (1998) Localization of neuroendocrine tumours with [111In] DTPA-octreotide scintigraphy (Octreoscan): a comparative study with CT and MR imaging. QJM 91(4):295301. https://doi.org/10.1093/qimed/91.4.295

46. Krausz Y, Keidar Z, Kogan I, Even-Sapir E, Bar-Shalom R, Engel A, Rubinstein R, Sachs J, Bocher M, Agranovicz S, Chisin R, Israel O (2003) SPECT/CT hybrid imaging with 111In-pentetreotide in assessment of neuroendocrine tumours. Clin Endocrinol (Oxf) 59(5):565-573. https://doi.org/10.1046/j.1365-2265.2003. 01885.x

47. Gabriel M, Decristoforo C, Donnemiller E, Ulmer H, Watfah Rychlinski C, Mather SJ, Moncayo R (2003) An intrapatient comparison of 99mTc-EDDA/HYNIC-TOC with 111In-DTPA-octreotide for diagnosis of somatostatin receptor-expressing tumors. J Nucl Med 44(5):708-716

48. Poeppel TD, Binse I, Petersenn S, Lahner H, Schott M, Antoch G, Brandau W, Bockisch A, Boy C (2011) 68Ga-DOTATOC versus 68Ga-DOTATATE PET/CT in functional imaging of neuroendocrine tumors. J Nucl Med 52(12):1864-1870. https://doi.org/10. 2967/jnumed.111.091165

49. Kabasakal L, Demirci E, Ocak M, Decristoforo C, Araman A, Ozsoy Y, Uslu I, Kanmaz B (2012) Comparison of ${ }^{68} \mathrm{Ga}$-DOTATATE and ${ }^{68} \mathrm{Ga}$-DOTANOC PET/CT imaging in the same patient group with neuroendocrine tumours. Eur J Nucl Med Mol Imaging 39(8):1271-1277. https://doi.org/10.1007/s00259-012-2123-y

50. Hofmann M, Maecke H, Börner R, Weckesser E, Schöffski P, Oei L, Schumacher J, Henze M, Heppeler A, Meyer J, Knapp H (2001) Biokinetics and imaging with the somatostatin receptor 
PET radioligand (68)Ga-DOTATOC: preliminary data. Eur J Nucl Med 28(12):1751-1757. https://doi.org/10.1007/s002590100639

51. Gabriel M, Decristoforo C, Kendler D, Dobrozemsky G, Heute D, Uprimny C, Kovacs P, Von Guggenberg E, Bale R, Virgolini IJ (2007) 68Ga-DOTA-Tyr3-octreotide PET in neuroendocrine tumors: comparison with somatostatin receptor scintigraphy and CT. J Nucl Med 48(4):508-518. https://doi.org/10.2967/jnumed. 106.035667

52. Hope TA, Bergsland EK, Bozkurt MF, Graham M, Heaney AP, Herrmann K, Howe JR, Kulke MH, Kunz PL, Mailman J, May L, Metz DC, Millo C, O'Dorisio S, Reidy-Lagunes DL, Soulen MC, Strosberg JR (2018) Appropriate use criteria for somatostatin receptor PET imaging in neuroendocrine tumors. J Nucl Med 59(1):66-74. https://doi.org/10.2967/jnumed.117.202275

53. Deroose CM, Hindié E, Kebebew E, Goichot B, Pacak K, Taïeb D, Imperiale A (2016) Molecular imaging of gastroenteropancreatic neuroendocrine tumors: current status and future directions. J Nucl Med 57(12):1949-1956. https://doi.org/10.2967/jnumed. 116.179234

54. Yadav D, Ballal S, Yadav MP, Tripathi M, Roesch F, Bal C (2020) Evaluation of $\left[{ }^{68} \mathrm{Ga}\right] \mathrm{Ga}$-DATA-TOC for imaging of neuroendocrine tumours: comparison with $\left[{ }^{68} \mathrm{Ga}\right] \mathrm{Ga}$-DOTA-NOC PET/CT. Eur J Nucl Med Mol Imaging 47(4):860-869. https://doi.org/10. 1007/s00259-019-04611-1

55. Gaertner FC, Plum T, Kreppel B, Eppard E, Meisenheimer M, Strunk H, Bundschuh RA, Sinnes JP, Rösch F, Essler M (2019) Clinical evaluation of $\left[{ }^{68} \mathrm{Ga}\right] \mathrm{Ga}$-DATA-TOC in comparison to $\left[{ }^{68} \mathrm{Ga}\right] \mathrm{Ga}$-DOTA-TOC in patients with neuroendocrine tumours. Nucl Med Biol 76-77:1-9. https://doi.org/10.1016/j.nucmedbio. 2019.08.006

56. Öberg K, Sundin A (2016) Imaging of neuroendocrine tumors. Front Horm Res 45:142-151. https://doi.org/10.1159/000442331

57. Cuccurullo V, Faggiano A, Scialpi M, Cascini GL, Piunno A, Catalano O, Colao A, Mansi L (2012) Questions and answers: What can be said by diagnostic imaging in neuroendocrine tumors? Minerva Endocrinol 37(4):367-377

58. Panagiotidis E, Alshammari A, Michopoulou S, Skoura E, Naik K, Maragkoudakis E, Mohmaduvesh M, Al-Harbi M, Belda M, Caplin ME, Toumpanakis C, Bomanji J (2017) Comparison of the impact of 68Ga-DOTATATE and 18F-FDG PET/CT on clinical management in patients with neuroendocrine tumors. J Nucl Med 58(1):91-96. https://doi.org/10.2967/jnumed.116.178095

59. Gillies RJ, Kinahan PE, Hricak H (2016) Radiomics: images are more than pictures, they are data. Radiology 278(2):563-577. https://doi.org/10.1148/radiol.2015151169

60. Lambin P, Leijenaar RTH, Deist TM, Peerlings J, de Jong EEC, van Timmeren J, Sanduleanu S, Larue RTHM, Even AJG, Jochems A, van Wijk Y, Woodruff $H$, van Soest J, Lustberg T, Roelofs E, van Elmpt W, Dekker A, Mottaghy FM, Wildberger JE, Walsh S (2017) Radiomics: the bridge between medical imaging and personalized medicine. Nat Rev Clin Oncol 14(12):749-762. https://doi.org/10.1038/nrclinonc.2017.141
61. Rizzo S, Botta F, Raimondi S, Origgi D, Fanciullo C, Morganti AG, Bellomi M (2018) Radiomics: the facts and the challenges of image analysis. Eur Radiol Exp 2(1):36. https://doi.org/10.1186/ s41747-018-0068-z

62. Aerts HJ, Velazquez ER, Leijenaar RT, Parmar C, Grossmann P, Carvalho S, Bussink J, Monshouwer R, Haibe-Kains B, Rietveld D, Hoebers F, Rietbergen MM, Leemans CR, Dekker A, Quackenbush J, Gillies RJ, Lambin P (2014) Decoding tumour phenotype by noninvasive imaging using a quantitative radiomics approach. Nat Commun 5:4006. https://doi.org/10.1038/ncomm s5006 (Erratum in: Nat Commun. 2014;5:4644. Cavalho, Sara [corrected to Carvalho, Sara])

63. Song T, Zhang QW, Duan SF, Bian Y, Hao Q, Xing PY, Wang TG, Chen LG, Ma C, Lu JP (2021) MRI-based radiomics approach for differentiation of hypovascular non-functional pancreatic neuroendocrine tumors and solid pseudopapillary neoplasms of the pancreas. BMC Med Imaging 21(1):36. https://doi.org/10.1186/ s12880-021-00563-x

64. Zhang L, Kang L, Li G, Zhang X, Ren J, Shi Z, Li J, Yu S (2020) Computed tomography-based radiomics model for discriminating the risk stratification of gastrointestinal stromal tumors. Radiol Med 125(5):465-473. https://doi.org/10.1007/ s11547-020-01138-6

65. Benedetti G, Mori M, Panzeri MM, Barbera M, Palumbo D, Sini C, Muffatti F, Andreasi V, Steidler S, Doglioni C, Partelli S, Manzoni M, Falconi M, Fiorino C, De Cobelli F (2021) CT-derived radiomic features to discriminate histologic characteristics of pancreatic neuroendocrine tumors. Radiol Med 126(6):745-760. https://doi.org/10.1007/s11547-021-01333-z

66. Gurgitano M, Angileri SA, Rodà GM, Liguori A, Pandolfi M, Ierardi AM, Wood BJ, Carrafiello G (2021) Interventional radiology ex-machina: impact of artificial intelligence on practice. Radiol Med 126(7):998-1006. https://doi.org/10.1007/ s11547-021-01351-x

67. Coppola F, Faggioni L, Regge D, Giovagnoni A, Golfieri R, Bibbolino C, Miele V, Neri E, Grassi R (2021) Artificial intelligence: radiologists' expectations and opinions gleaned from a nationwide online survey. Radiol Med 126(1):63-71. https://doi.org/10.1007/ s11547-020-01205-y

68. Grassi R, Miele V, Giovagnoni A (2019) Artificial intelligence: a challenge for third millennium radiologist. Radiol Med 124(4):241-242. https://doi.org/10.1007/s11547-019-00990-5

69. Neri E, Coppola F, Miele V, Bibbolino C, Grassi R (2020) Artificial intelligence: Who is responsible for the diagnosis? Radiol Med 125(6):517-521. https://doi.org/10.1007/ s11547-020-01135-9

Publisher's Note Springer Nature remains neutral with regard to jurisdictional claims in published maps and institutional affiliations. 